Studia Judaica 21 (2018), nr 1 (41), s. 7-30

doi:10.4467/24500100STJ.18.002.9172

Magdalena Koch

\title{
Lost-Regained-Revised: Laura Papo Bohoreta, Sephardic Women in Bosnia, and Transcultural Survival Strategies in Memory
}

\begin{abstract}
This paper specifies and describes the main four stages and strategies of intercultural and memory survival of Sephardic women in Bosnia in the past (during the interwar period) and in the contemporary world (before, during, and after the collapse of Yugoslavia). The first strategy, named here as a (manu)script and orality/textuality one, is illustrated by a study Sephardic Woman in Bosnia (1932) by Jewish Sarajevo feminist Laura Papo Bohoreta (1891-1942). The second one, labeled as a translation and print strategy, is connected with the activity of Muhamed Nezirović (1934-2008), especially his translation of Papo's book from Ladino into Bosnian (2005). The third one, recognized here as a cultural transfer strategy, is represented by the novels The Scent of Rain in the Balkans (1986) and The Ballad of Bohoreta (2006) by contemporary Serbian female writer Gordana Kuić (1942). And-last but not least—-the fourth strategy of digitizing manuscripts and archival texts by Laura Papo is represented by Edina Spahić, Cecilia Prenz Kopušar, and Sejdalija Gušić, a team who prepared and has recently edited three collected books with Papo's manuscripts (2015-2017).
\end{abstract}

Keywords: Sephardic women, memory strategies, orality/textuality, cultural transfer, digitizing archival texts, Laura Papo, Muhamed Nezirović, Gordana Kuić. 


\section{Introduction}

"Little has been written about the history of women in former Yugoslavia and even less is as yet known about the history of Jewish women in the Balkans," noted, in 2009, Harriet Freidenreich, professor emerita of history at Temple University in Philadelphia and a specialist in Jewish history, European women's history, and gender history. While her first assertion is thankfully slowly losing currency due to a significant rise over the past quarter century in the number of books and interdisciplinary projects focused on women in the culture and history of the former Yugoslavia, which have been systematically filling this lamentable gap in cultural history, ${ }^{2}$ the latter part of her claim, unfortunately, still appears to hold true. There continue to be few books available about Jewish women of the former Yugoslavia, ${ }^{3}$ and to this day, this group has not

${ }^{1}$ Harriet Freidenreich, "Yugoslavia," Jewish Women: A Comprehensive Historical Encyclopedia, Jewish Women's Archive (2009), https://jwa.org/encyclopedia/article/Yugoslavia [retrieved: 12 Oct. 2017].

${ }^{2}$ I will list here as examples titles from various areas (history of literature, history, biography, mediaeval history, cultural history), but it needs to be emphasized that this list is far from complete. Cf. Celia Hawkesworth, Voices in the Shadows: Women and Verbal Art in Serbia and Bosnia (Budapest, 2000); Magdalena Koch, Podróże w czasie i przestrzeni: Proza Isidory Sekulić (Wrocław, 2000); Francisca de Haan, Krasimira Daskalova, Anna Loutfi (eds.), A Biographical Dictionary of Women's Movements and Feminisms: Central, Eastern, and South Eastern Europe, 19th and 20th Centuries (Budapest, 2005); Biljana Dojčinović Nešić, GendeRings: Gendered Readings in Serbian Women's Writing (Beograd, 2006); Magdalena Koch, Kiedy dojrzejemy jako kultura: Twórczość pisarek serbskich na poczatku XX wieku (kanon - genre - gender) (Wrocław, 2007), Serbian expanded edition: ead., Kada sazremo kao kultura, trans. Jelena Jović (Beograd, 2012); Svetlana Tomin, Knjigoljubive žene srpskog srednjeg veka (Novi Sad, 2007); Slobodanka Peković, Isidorini oslonci (Novi Sad, 2009); Ivana Hadži Popović, Isidora - eros i tajna (Beograd, 2009); Slavica Garonja Radovanac, Žena u srpskoj književnosti (Novi Sad, 2010); Dunja Detoni Dujmić, Ljepša polovica književnosti (Zagreb, 1998); Maša Grdešić (ed.), Mala revolucionarka: Zagorka, feminizam i popularna kultura (Zagreb, 2009); Natka Badurina, Nezakonite kćeri ilirije: Hrvatska književnost i ideologija u 19. i 20. stoljeću (Zagreb, 2009); Andrea Zlatar, Tekst, tijelo, trauma: Ogledi o suvremenoj ženskoj književnosti (Zagreb, 2004); Jasmina Čaušević (ed.), Zabilježene - Žene i javni život Bosne i Hercegovine u 20. vijeku, 2nd edition (Sarajevo, 2014), https://pl.scribd.com/doc/258137781/Zabiljezene-Zene-i-Javni-Zivot-Bosne-iHercegovine [retrieved: 7 Nov. 2017); Ivana Pantelić, Partizanke kao građanke: Društvena emancipacija partizanki u Srbiji 1945-1953 (Beograd, 2011); Neda Todorović (ed.), Izuzetne žene Srbije XX $i$ XXI veka / Exceptional Women of Serbia XX and XXI century (Beograd, 2016). Also important is the digital interactive feminist project "Knjiženstvo, teorija $i$ istorija ženske književnosti na srpskom jeziku do 1915. godine," financed by the Ministry of Education, Science and Technological Development of the Republic of Serbia under the project no. 178029 (2011-2017).

${ }^{3}$ One of the first to write about them was Dina Katan Ben-Zion in her Ph.D. thesis, followed by a book titled Nashim kotvot 'olam: sofrot yehudiyot be-Yugoslavia leshe-avar (Je- 
yet been the subject of a major work of cultural history. Although this phenomenon arouses objections and a growing sense of frustration, it is really not surprising, as there has long been a great deal of negligence in this area of study in general. Up until the 1990s, knowledge about the participation of women in various fields was quite modest, so filling gaps here will remain an ongoing process that will continue for years to come. It can even be said that in research this field had been previously pushed to the margins, most likely out of the belief that it was of little importance, because it did not seem to contribute much to findings or narratives of a general and universal nature. Such a way of thinking, which has persisted for centuries, reflects a general, though in my opinion, erroneous belief that the voices of women in culture do not bring/add anything new. This situation has caused the voice of Jewish women from the Balkan periphery of Europe to be ignored all the more because they had even less influence and visibility than women representing the majority cultures in the region (e.g. Serbian, Croatian). It should be remembered that Jews in the Balkans (and therefore in the areas encompassing the former Yugoslavia) have always belonged to a minority ethnic group. This holds true regardless of whether we are talking about the Sephardic community, which after being expelled from the Iberian Peninsula in 1492 settled in various places on the Balkan Peninsula in the sixteenth century (especially in Istanbul and Thessaloniki, but also in Skopje, Bitola, Dubrovnik, Split, Sarajevo, and Belgrade), or about the Ashkenazi community, which came to the Balkans only in the midnineteenth century, especially after the Congress of Berlin in 1878, as a result of which Bosnia and Herzegovina came under the patronage of the Austro-Hungarian Empire; this was also a time when a major migration was taking place among the Jewish population within the Habsburg Monarchy overall. ${ }^{4}$ This does not change the fact that both groups were deeply immersed in the multiculturalism of the Balkans. My primary interest here, however, is the situation in (former) Yugoslavia and the

rusalem, 2013), as well as in her article, see ead., "The Feminine Voyage in the Post-Holocaust Jewish Literature of Former Yugoslavia," Interkulturalnost. Ċasopis za podsticanje i afirmaciju interkulturalne komunikacije 7 (2014), 186-191. Another book was also recently published, Jagoda Večerina Tomaić, Bohoreta - najstarija kći (Zagreb, 2016), based on the author's doctoral dissertation.

${ }^{4}$ Cf. Nebojša Popović, Jevreji u Srbiji: 1991-1941 (Beograd, 1997), 11-24; Joseph J. Lévy, Yolande Cohen, Żydzi sefardyjscy: Odyseja sefardyjskich Żydów od czasów inkwizycji do naszych dni, 1492-1992, trans. Krzysztof Pruski (Warsaw, 2005), 50-51. 
multilingual mosaic of languages spoken there: in the regions historically under the influence of the Ottoman Empire from the sixteenth to the nineteenth century, the Turkish language was dominant, while in the areas of influence of the Habsburg Monarchy, German and Hungarian prevailed, and after 1918, that is, following the creation of a common state of southern Slavs-the Kingdom of Serbs, Croats, and Slovenes (renamed the Kingdom of Yugoslavia in 1929)—Slavic culture and the Serbian/Croatian/Bosnian language system achieved a dominant position. These processes involving external linguistic influences overlap with Jews' own nurturing of their cultures and languages: Ladino (Sephardim) and Yiddish (Ashkenazim). The Sephardic community in particular was actively dedicated to nurturing and developing the traditions it had carried with it from the Iberian Peninsula, and, hence, remained relatively closed, fending off assimilation processes and preserving its cultural heritage in as pure a form as possible. It developed in its own, isolated environment, in which it preserved its Jewish identity in Bosnia and Herzegovina through the Ladino language (Judeo-Spanish) and cultivation of traditions. ${ }^{5}$

I am focusing my reflections here on Sephardic Jewish women in an effort to help fill the aforementioned gaps, and restore both the herstorical (matrilineal, feminine) and historical (complementing mainstream history) memory of their culture, which it undoubtedly deserves. The primary motif used here in relation to Balkan Jewish women who were active in culture will be the Miltonian paradigm, which has been preserved in culture and revolves around a triad of concepts: lost-regained-revised. As Moshe Rosman has emphasized in writing about Jews in general, without any specification of gender: "Wherever they lived, Jews were a minority, usually a colonized one, whose identity depended on being defined apart from the majority while in truth they were more a part of the society in which they lived than separate from it." 6

Given such a situation, Sephardic Jewish women can be seen as having been doubly marginalized for centuries, not only in the official cultural discourse of their region, but until recently, also in research. For one, they have largely gone unnoticed, as members of an ethnic minority regarded

5 This topic has been treated more broadly in Krinka Vidaković-Petrov, Kultura španskih Jevreja na jugoslovenskom tlu: XVI-XX vek (Sarajevo, 1990; 1st edition 1986), and in Muhamed Nezirović, Jevrejsko-španjolska književnost (Sarajevo, 1992), particularly 7-72.

${ }^{6}$ Moshe Rosman, How Jewish is Jewish History? (Oxford, 2007), 32. 
as peripheral in both Bosnia and Serbia (I am limiting the scope of my enquiry to these communities, though it most certainly reflects a broader "Balkan perspective"); secondly, as women, they have been invisible among their own people in public discourse due to their inferior gender position, a situation we can associate with the phenomenon of "structural amnesia." Their inscription in memory as a distinct group and as a subject of specialized studies has faced a double challenge. Now, after years of having been lost, the memory of them is slowly being restored, and their place in culture "revised." I would like to introduce here an important Sephardic woman from Bosnia, Laura Papo Bohoreta, ${ }^{8}$ in order to distinguish several strategies due to which, in my opinion, Yugoslav Jews have managed to survive in memory and culture in the twentieth and twenty-first centuries, and are slowly becoming the subject of separate analyzes within Sephardic studies.

\section{Sephardic Women from Bosnia and Laura Papo Bohoreta}

Laura Papo Bohoreta (b. Luna Levi, 1891-1942) represents a cornerstone in the Sephardic Jews' strategies for survival in memory and culture. The first prominent Sephardic female intellectual, and an author, folklore collector, campaigner, and feminist, she was particularly active during World War I and the interwar period. ${ }^{9}$ She was born in Sarajevo in Bosnia

7 This term was introduced in 1947 by John A. Barnes for his study of genealogies. It describes the process of remembering only those family/cultural links that are of social significance (they are thus strongly patrilineal and patriarchal). It also refers to the process of forgetting the names of ancestors who are not recognized as an important link: male lines are far more memorable than female ones. John A. Barnes, "A Structural Amnesia," in id., Models and Interpretations: Selected Essays (Cambridge, 1947).

${ }^{8}$ Bohoreta was her nickname because this is the name traditionally given to the firstborn daughter in Sephardic families (the first-born son was given the analogous nickname Bohor/Behor).

${ }^{9}$ Among the first to focus critical attention on Laura Papo were Vidaković-Petrov, Kultura španskih Jevreja, and Nezirović, Jevrejsko-španjolska književnost. Very active were also Eliezer Papo and Željko Jovanović. See Eliezer Papo, "Entre la modernidad y la tradición, el feminismo y la patriarquía: Vida y obra de Laura Papo 'Bohoreta,' primera dramaturga en lengua judeo-española," Neue Romania 40 (2011), 89-107; id., "Laura Papo-Bohoreta: Kommentierte Forschungsbibliographie zum literarischen Werk einer bosnischen Sefardin," Transversal: Zeitschrift für Jüdische Studien 13 (2013), 2:65-80; see also Željko Jovanović, "Endangered Judeo-Spanish Folk Material: Collection, Re-creation and Recovery by Twentieth-Century Sephardic Authors from the Former Yugoslavia" (Ph.D. dissertation, University of Cambridge, 2015, supervisors: Dr. Louise Haywood and Prof. Alison Sinclair). Jovanović devoted the whole long chapter to Laura Papo Bohotera, especially pages 10-85. I am very grateful to the author for making the text of his Ph.D. in a pdf form 
as Luna ${ }^{10}$ Levi, and between 1900 and 1908 lived with her family in Istanbul, where she attended the Alliance Israélite Universelle school for Jews. ${ }^{11}$ In the interwar period, she became active in the Jewish community in Sarajevo and Bosnia, where she promoted the development of culture in the Ladino language, and was a central figure in Jewish life there. In 1942, she died of illness in Sarajevo, where she was buried in an unmarked grave during World War II, perhaps unaware that her two sons, Leon (b. 1918) and Bar-Kokhba (b. 1919), had died during their deportation by Croatian fascists to the extermination camp in Jasenovac. ${ }^{12}$ She set for herself the project of recording the personal histories

accessible to me. In Poland, works focusing on her have included: Aleksandra Twardowska, "La mužer sefardi de Bosna: Literacka i kulturalna działalność Laury Papo-Bohorety," in Katarzyna Taczyńska, Szymon Sochacki, Miloš Zečević (eds.), Poznać Batkany: Historia Polityka - Kultura (Toruń, 2011), 205-213; and Agata Jawoszek, "Czwarty element - obecność w przestrzeni kulturalnej Bośni i Hercegowiny sefardyjskich Żydów a motyw Sarajewa jako Małej Jerozolimy," Południowosłowianskie Zeszyty Naukowe 8 (2011), 123-133. In 2006, Anetta Buras-Marciniak wrote a doctoral dissertation at the University of Łódź titled "Żydzi sefardyjscy w dziejach, literaturze i kulturze Bośni i Hercegowiny" (her advisor was Zdzisław Darasz). The dissertation was never published, however, and its influence has been unfortunately very limited.

${ }^{10}$ As Jagoda Večerina Tomaić has written in her book on Laura Papo, the name Luna was changed to Laura during the family's stay in Istanbul (1900-1908) for assimilation purposes, in order to hide her Sephardic origins while living in this foreign environment. Cf. Večerina Tomaić, Bohoreta - najstarija kći, 24. When she married the Sephardic Jew Danijel Papo in 1916, she began to write under her husband's surname and has since then been known as Laura Papo.

11 This organization was founded in Paris in 1860 by Adolphe Crémieux, a French Jewish lawyer, to protect the rights of Jews in various countries, but it was also a platform for promoting mutual support, solidarity, unity, and professional development. Over time, especially after 1890 , it expanded its mission to include improving the welfare and education of Jews in the Middle East, the Balkans, and North Africa through contact with French culture and language. Its first schools were opened in Africa (Morocco) and Asia (Baghdad). In total, more than sixty schools operated in the Ottoman Empire in the Middle East, Iran, and North Africa. Jewish children were provided with both a primary and vocational education. Many teachers educated in Alliance schools for teachers later worked in Turkey and France. See Frances Malino, "Jewish/Israel Organizations: Alliance Israelite Universelle," Jewish Virtual Library, https://www.jewishvirtuallibrary.org/jsource/judaica/ ejud_0002_0001_0_00834.html [retrieved: 10 Jan. 2017]. Laura Papo also graduated from such a school in Istanbul, and hence knew French well; she later spent six months at Alliance Française in Paris at the Sorbonne, where she obtained a diploma entitling her to teach French and literature.

12 Jasenovac was a concentration camp established during World War II by Croatian fascists (Ustaše) as part of the Independent State of Croatia. It operated from August 1941 to April 1945 and is known as the "Auschwitz of the Balkans" or the "Croatian Auschwitz." It was used as a place for the extermination of Jews, Serbs, Roma, and Croatians from the resistance movement. To this day, there are disputes between Croatian and Serbian politicians about the number of victims killed there. 
of Sephardic women in Bosnia and showing this group as relevant to the development of the community and its cultural heritage. Although she was an educated and outward-looking person, from 1924 onward she chose to write mainly in Ladino (in its local, Bosnian version, though she was fluent in French, ${ }^{13}$ Spanish, German, Turkish, and Serbo-Croatian), which functioned as her symbolic fatherland/motherland. She portrayed the world and daily life of Sephardic women in her short stories, plays, poems, and, above all, in her monograph La mužer sefardi de Bosna [The Sephardic Woman in Bosnia]. Yet, as she herself emphasized, she did not aspire to write high-brow, artistic literature, as her prime object was to serve as a guardian of not only her own traditions and culture but also, and above all, of the memory of Sephardic women and their sociocultural roles. ${ }^{14}$ They were to be credited, she insisted, with the passing down of traditions, customs, and language from one generation to the next, and thus reinforcing the memory of their group and not allowing its culture, origins, and roots to be forgotten. Raising the consciousness of Sephardic women, showing them their cultural potential (i.e. who they were/could be, how they embodied and built upon the strength of generations of women who had come before them), emphasizing their social role through continuity in preserving Jewish customs, rituals, rites, cuisine, folklore, and, above all, the Ladino language, became a lifelong mission for her. In this sense, she could be called the first Sephardic feminist, who exerted a tremendous influence on this community and on the culture and forms of remembrance related to it. Her goals were largely educational and pragmatic: to preserve the world of Sephardic women, to salvage it from oblivion, to kindle the memory of them, and, importantly, to convey her own admiration for the adaptive capacities of women from her culture and their forebears. She wrote about them analytically and with undisguised fascination in 1931, realizing that many of the elements of this world were undergoing rapid, deep transformations and, as a result, were in danger of being forgotten:

${ }^{13}$ It was in this language that she made her debut in 1908, writing a play in five acts titled Elvira under the pseudonym Laure Yvlé (reversed parts of her surname Levy). She was also the author of translations and adaptations from French: in 1907 she translated a play by Mme Émile de Girardin, La joie fait peur: La alegria espanta (Veselje plaši / Joy Frightens), and in 1910 the Jules Verne novel Les enfants du capitaine Grant (Djeca kapetana Granta / In Search of the Castaways). Cf. Večerina Tomaić, Bohoreta - najstarija kći, 38-44, 105-113.

${ }^{14} \mathrm{Cf}$. on this subject Vidaković-Petrov, Kultura španskih Jevreja, and Nezirović, Jevrejsko-španjolska književnost. 
Let us examine carefully the life of a woman in her sixties $!^{15}$ Her childhood was spent in a Turkish (Muslim) setting in the purest Orient. When she became an adolescent, the Austrians came ${ }^{16}$ and with them European elements, which turned her notion of life upside down. How else? Once a woman of the harem, she had to adapt, willy-nilly, to the customs that the new conqueror brought in and the new government decreed. And when she reached the age when one becomes a grandma, Serbians liberated Bosnia ${ }^{17}$ and she, a little Jewish girl . . . has kept adjusting shrewdly to all these regimes as her race's adaptive capacities prompted her to. Over half a century, she has watched three empires succeed each other, and she has lived in three environments-Oriental, Germanic and Slavic. And she's always been able to keep pace with her times. Now, doesn't that take great art? ${ }^{18}$

\section{(Manu)script: From Orality to Textuality}

The first strategy of the Sephardic women's community for survival in communicative and cultural memory was writing (down) - the act of (re)constructing history. This foundational act of memory is associated in Bosnia with the figure of Laura Papo. The impetus for her telling and preserving the history of Sephardic Jewish women was an article by the South Slavic feminist, ethnographer, cultural activist, teacher, and intellectual Jelica Belović Bernadžikovska (1870-1946), ${ }^{19}$ entitled "Die südslavische Frau in der Politiek" and printed in the Bosnische Post ${ }^{20}$ (no. 281, 10 Dec. 1916), a German-language daily published in Sarajevo, which provided the impulse for a detailed telling and consolidation of the history of Sephardic Jewish women. Belović Bernadžikovska devoted a section of her article to them; not knowing much about this hermetic community, she described these women in a superficial and unfavorable way, writing about their passivity, patriarchal subordination, their being limited to traditional roles, and their backwardness in comparison with women of other ethnic groups in Bosnia. A week later, in the same newspaper Laura Papo responded polemically

${ }^{15}$ Born ca. 1870.

${ }_{16}$ After 1878, following the Congress of Berlin, Bosnia became a protectorate of the Austro-Hungarian Empire for 30 years, and was then annexed in 1908.

17 This refers to the Kingdom of Serbs, Croats, and Slovenes, created in 1918.

${ }^{18}$ Laura Papo Bohoreta, Sefardska žena u Bosni (Sarajevo, 2005), 65.

${ }^{19}$ For more on this author see: http://knjizenstvo.etf.bg.ac.rs/sr/authors/jelica-belovicbernadzikovska [retrieved: 24 Oct. 2017] and the Croatian Bibliographic Lexicon (Hrvatski bibliografski leksikon), http://hbl.lzmk.hr/clanak.aspx?id=1671 [retrieved: 24 Oct. 2017].

${ }^{20}$ For a time, the co-founder and editor-in-chief of the German-language newspaper Bosnische Post, published in Sarajevo from 1884 to 1918, was the first female journalist and editor in Bosnia, Milena Mrazović-Preindlsberger (1863-1927). 
with an article titled "Die spaniolische Frau" (Bosnische Post, no. 287, 17 Dec. 1916), ${ }^{21}$ in which she defended Sephardic women. ${ }^{22}$ Muhamed Nezirović, a dedicated researcher of Bohoreta's legacy and translator of her work (which will be discussed later in more detail), mentions another text by Belović Bernadžikovska titled "Die spaniolische Frau in Bosnien" from 1917, for which no response from Bohoreta appeared in the press. ${ }^{23}$ A comprehensive response, however, came in the form of her in-depth study La mužer sefardi de Bosna. According to Papo's own account, she was encouraged to write it by Dr. Vit Kajon, a collector of Jewish folklore in Bosnia. She chose to abandon German as a medium of communication and her superficial, reactive and emotional polemic with her opponent in the daily press. Instead, she turned to her native language, Ladino, seeing the writing of an in-depth ethnographic study as a chance not only for a comprehensive, substantive, factual description, but, moreover, as an opportunity to produce a detailed and accurate record of a passing world, and thus save from obscurity the traditions of her own culture, endangered in the interwar period both by increasingly strong assimilation processes among Jews, and by the slow, steady rise of fascism throughout Europe. In doing so, she drew attention to a group that was among the most marginalized, but also very close to her-Sephardic women.

We should recall that before World War I, throughout Europe (and thus also in the south, both in the Kingdom of Serbia and in AustriaHungary, which included Bosnia and Herzegovina), the movement for the emancipation of women was spreading rapidly, and after the creation of the Kingdom of Serbs, Croats, and Slovenes/Yugoslavia, activism among feminist movements in the region increased greatly. ${ }^{24}$ Papo herself, as well as her sisters (Nina, Klara, Blanka, and Rifka-Rikica), ${ }^{25}$ became examples

${ }^{21}$ This issue was studied by Muhamed Nezirović, "Predgovor," in Papo Bohoreta, Sefardska žena u Bosni, 31-34.

${ }^{22}$ This "harsh polemic" ("žestoka polemika”) with Belović Bernadžikovska's article is mentioned by Papo Bohoreta herself in the Introduction ("Uvod") to her book. Cf. Papo Bohoreta, Sefardska žena u Bosni, 41-42. At the end of this book there is a copy of the manuscript for this article written in German (11 pages in total).

${ }^{23}$ Cf. Nezirović, "Predgovor," 33.

${ }^{24}$ This has also been written about by: Neda Božinović, Žensko pitanje u Srbiji u XIX i XX veku (Beograd, 1996); Koch, Kiedy dojrzejemy jako kultura; ead., "Slavica non leguntur: On a Feminist Project in Interwar Yugoslavia," Przekładaniec: A Journal of Literary Translation 24 (2010), 131-143, https://www.wuj.pl/UserFiles/File//Przekladaniec_EN_24-7_prev. pdf [retrieved: 24 Oct. 2017]; Čaušević (ed.), Zabilježene.

${ }_{25}$ All were forced to work professionally: Nina and Klara opened the Chapeaux Chic Parisien milliner's shop in Sarajevo in 1911, Blanka worked in a tobacco shop, and Rifka 
of emancipation processes at work among Sephardic women, with Papo already then being considered (and still is) the first Sephardic feminist in Bosnia. ${ }^{26}$ In her strategy of remembering, however, the issues of concern to her included both the past and the future of women from within her culture, and thus oscillated between tradition and modernity, or as Jagoda Večerina Tomaić writes, "between feminism and tradition." ${ }^{27}$ Reading Papo's texts (poems, stories, articles), listening to her lectures, or watching her dramas or songs in Ladino on stage, women were simultaneously being not only educated and emancipated, but also reminded of their origins, history and culture-of their roots. In many texts, Papo challenged the stereotype of the passive, patriarchal, illiterate Sephardic woman, which also seemed to be a polemical act directed against the aforementioned description of Belović Bernadžikovska. Papo's priority was to educate women, to strengthen the educational component of their lives, because this would bring them independence from their male "guardians" (father, brothers, husband, sons). She also stressed the important role played by women in the community-she indicated education and work (as a means for independent living) as imperatives in their lives. In her stories and dramas, as well as in her active engagement as a cultural animator, social activist, Sephardic folklorist, and educated working woman (who raised two sons on her own after her husband Danijel Papo's mental illness and death), she provided models and incentives for self-development to Sephardic women, and tried to help them equip themselves to meet the requirements of the modern day, and thereby attain greater independence. Večerina Tomaić has even made the claim that in the interwar period, especially in the 1930s, Papo Bohoreta felt that the oral traditions, culture, and Ladino language of the Sephardic Bosnian community, threatened by processes that were leading to its slow extinction, would soon be forgotten. ${ }^{28}$ She realized that one strategy for the survival of the community and its history was to save its language, proverbs, customs, and songs as primary carriers or storehouses of memory. For this reason, she treated the past as an important link in ensuring the continuity of her culture, though she was primarily interested in the matrilineal order and the role of Sephardic women as the guardians of tradition and language.

was a ballet dancer during the interwar period in the National Theatre in Belgrade. Cf. Večerina Tomaić, Bohoreta - najstarija kći, 24.

${ }^{26}$ This is how she is described in the first book on Laura Papo. Cf. ibid., 6, 12-15.

27 Ibid., 35-37.

${ }^{28}$ Cf. ibid., 59. 
In this context, it is not at all surprising that Papo Bohoreta gave up defending Sephardic women by means of polemics with other cultures (German/Austrian or Bosnian/Serbian/Croatian), and instead turned to these women directly, from within their shared Jewish heritage. She meticulously collected and gathered fragments of tradition into a coherent whole, combining them, describing them, and saving them from being lost to memory—-s ljubavlju i poštovanjem otima zaboravu" ("with love and respect saved from oblivion"). ${ }^{29}$ An example of this strategy for surviving in culture through the reconstruction of a community's recent traditions was the aforementioned ethnographic study on Jewish women. From July 1931 to August 1932, Laura Papo produced more than one hundred copybook pages of tiny handwriting that added up to her cultural, ethnographic, and folklore study La mužer sefardi de Bosna, devoted exclusively to the women of her own culture. Its thirty-four chapters present a panorama of life that she knew from the oral tales of two generations of Sephardic women-mothers and grandmothers. Papo shows a variety of aspects of women's everyday comings and goings—-starting from their looks and garments, to cuisine, to their entertainments and neighborly relations. She describes festivals and rituals but also hygienic practices, basic medical knowledge, the course and customs of pregnancy, childbirth, the postnatal period, the naming of a child, maternity, matchmaking, conjugal life, and widowhood. The book ends with reflections on old age and death, including a detailed description of the preparation of clothes for the deceased, the rituals of mourning, and funeral prayers. In this way, the author participates in memory-making through her communicating with the community of Sephardic women. Within this relatively small community, she became an important link in the living communicative memory. ${ }^{30}$ Moreover, the orality of Bohoreta's message is replaced by textuality; she described details, working within the "modus of biographical memories,"31 referring to the experiences of a group of Sephardic women she herself knew, including those of her own mother, Estera. She was the first person to

${ }^{29}$ Ibid., 101.

${ }^{30}$ I refer here to Jan Assmann's concept of communicative memory. See: Jan Assmann, "Communicative and Cultural Memory," in Astrid Erll, Ansgar Nünning (eds.), Cultural Memory Studies: An International and Interdisciplinary Handbook (Berlin, 2008), 109-118; see also: Jan Assmann, John Czaplicka, "Collective Memory and Cultural Identity," New German Critique 65 (1995), 125-133.

31 Jan Assmann, "Kultura pamięci," in Magdalena Saryusz-Wolska (ed.), Pamięć zbiorowa i kulturowa: Wspótczesna perspektywa niemiecka, trans. Anna Kryczyńska-Pham (Kraków, 2009), 89. 
give testimony to the history of the women within her own cultural circle, enriching and authenticating the image of a community that had been thus-far closed and inaccessible to others, recording it in a textual (though handwritten) medium. Her text was intended to serve-as Assmann would say-a mnemonic function, ${ }^{32}$ that is, to maintain the memory and identity of Sephardic women, and, at the same time, to overcome stereotypes based on the false outsider perceptions of her recent adversary Belović Bernadžikovska. By writing this work, Papo fulfilled her social, community, and gender obligation to salvage memory by creating a record that constitutes a unique document of the epoch, and by becoming the guardian of the Bosnian/Sarajevo Sephardic women's collective memory, the memory that provides stability to their social identity within the wider context of women in Bosnia. The writtendown text proved to be an act of restoration of vanishing meanings, a form of "externalized memory." 33 The strength and, at the same time, a weakness of this strategy back then (during the interwar period) lay in her use of the local dialect of Ladino, isolated from a wider context, and the handwritten form of the copybook notes. Although the language played a crucial role in cultural communication and identity-perpetuation among Sephardic Jews and acted as a storehouse for their collective cultural memory, ${ }^{34}$ it also restricted access to knowledge about these women, making it available only to members of the Sarajevo Sephardic community. More importantly and rather essentially, the strategy of writing (down) in Ladino was blighted by the fact that the study had no printed form and remained a manuscript only. ${ }^{35}$ As such, the work of memory-making through the communication and preservation of cultural lore and meanings among Sephardic women in Bosnia had been done, but its reach was severely limited, if we can speak of any reach at all. However, against all odds, Papo's text has proven to be a valuable repository of social traditions and communication. The strategy

32 Cf. also Tomasz Majewski, "Mnemotechnika," in Magdalena Saryusz-Wolska, Robert Traba (eds.), Modi memorandi: Leksykon kultury pamięci (Warsaw, 2014), 240-245.

${ }_{33}$ Jan Assmann, Pamięć kulturowa: Pismo, zapamiętywanie i polityczna tożsamość w cywilizacjach starożytnych, trans. Anna Kryczyńska-Pham (Warsaw, 2008), 39. English edition: id., Cultural Memory and Early Civilization: Writing, Remembrance, and Political Imagination (Cambridge, 2011).

${ }^{34}$ Cf. Jacques Le Goff, Historia i pamięć, trans. Anna Gronowska, Joanna Stryjczyk, introd. Paweł Rodak (Warsaw, 2007), 103. English edition: id., History and Memory, trans. Steven Rendall, Elizabeth Claman (New York, 1992).

${ }^{35}$ Unfortunately, to date nobody has been able to answer the question why this book was never printed in Ladino before World War II. 
of (hand)writing was important insofar as it promoted survival, even if only in a time capsule, in a "dormant" form and in an easily perishable and risky carrier of memory (just how risky was shown by the experience of the Holocaust). It is hard to disagree with the statement of Andreas Huyssen that the "past is not simply there in memory, but it must be articulated to become memory." ${ }^{36}$ The story of Sephardic women was articulated by Bohoreta, but it was exposed to the risk of annihilation, because it existed in the form of a single, unique item and was preserved in the idiom of a minority, moreover, one condemned during World War II to systematic extermination. The strategy of preserving the history of women in the form of a manuscript and in the short-range of the Ladino language in Bosnia could have been proven over time to be insufficient, had it not been for another strategy applied to the text of The Sephardic Woman in Bosnia years later.

\section{Translation and Print}

The second strategy has been that of translation and publishing, a strategy used in the early twenty-first century by University of Sarajevo professor Muhamed Nezirović (1934-2008), a Romance studies scholar and distinguished expert on Sephardic culture. After a "floating gap" ${ }^{37}$ of more than seventy years, Nezirović first discovered Laura Papo, describing her in his Jevrejsko-španjolska književnost u Bosni i Hercegovini [History of Judeo-Spanish Literature in Bosnia and Herzegovina], ${ }^{38}$ and then also writing about her study of Sephardic women. The "floating gap," as Assmann wrote, recalling a term coined by Jan Vansina, ${ }^{39}$ is the distance in time between communicative memory and cultural memory, a gap between the community of experience that bonds past and future

${ }^{36}$ Andreas Huyssen, Twilight Memories: Making Time in a Culture of Amnesia (New York, 1995), 3.

37 Through a lucky twist of fate-felix casus, as Muhamed Nezirović would call itLaura Papo's manuscripts survived in the Sarajevo Municipal Archives, though they had been held previously in the private archive of the Levi family, where they survived World War II. Most of the manuscripts were sold to the City Archives in the 1960s by Bohoreta's sister, Blanka (née Levi) Kuić, who lived in Belgrade. The remaining part was given to the institution in the late 1980s by the author's niece, Gordana Kuić, a writer herself, which will be discussed later in my text.

${ }^{38} \mathrm{He}$ described her in his book as an important figure in Sephardic cultural life. Cf. Nezirović, Jevrejsko-španjolska književnost, 503-556.

39 Jan Vansina, Oral Tradition as History (Madison, 1985), 23. 
generations, and the cultural symbolization of the world of the descendants that comes into being many years later. ${ }^{40}$ From within this fluid temporal chasm, Nezirović, who was an accomplished researcher of Romance languages and knew Ladino fluently, rescued for a second time and in a double sense both this text and the figure of Bohoreta from the realm of oblivion. He made an active effort at reviving the memory and reinforcing the cultural memory of Sephardic women from Bosnia, joining a succession of guardians of their memory. He first translated The Sephardic Woman in Bosnia from Ladino into Bosnian, and then published it in Sarajevo in 2005. The book thereby made its first public appearance, though in a language (Bosnian) that was "secondary" to the original vehicle of memory. Secondly, he also preserved the memory of Laura Papo herself, demonstrating her importance as an animator of Sephardic culture, and prefaced the translation of her study with a comprehensive introduction titled "Predgovor: Sudbina jednog nepoznatog a značajnog pisca" [Preface: The Fate of an Unknown but Important Writer]. It should be noted that the publisher of the book in Bosnia was the Connectum publishing house, which emphasized its role in "bridging" cultures, in this case, Sephardic and Bosnian. In line with the publisher's philosophy of integrating the cultural heritage of Bosnia, it took pains to produce a beautiful bilingual collector's edition (Ladino manuscript on the left, Bosnian text on the right) with a rich graphic design that featured the author on the front cover. The book's preface also contains photographs of Papo with her sons and sisters, and at the end of the book, there are a number of historical images of Sephardic women from the nineteenth and twentieth centuries. In addition, the book includes an afterword by Dragana Tomašević, a Bosnian-Herzegovinian writer and researcher of women's activity in Bosnia and Herzegovina, titled "Pogovor: Jedan književni biser" [Afterword: A Certain Literary Pearl], in which the author stresses the importance of Papo's writing to the study of the culture of women in Bosnia in general, and emphasizes the emancipationist and even feminist context of Papo's newly translated and published book. After having long existed within the realm of an almost lost communicative memory, her work was recovered and revitalized by joining two strategies side by side (the bringing together of the handwritten text and print, and of the Ladino and Bosnian languages). The published text began to serve as the

40 Assmann, Pamięć kulturowa, 64. 
founding text of the cultural memory of Bosnia's Sephardic women, and still functions in this role today. Consequently, an important context for the maintenance of memory is the fact that during the period of the floating gap, Papo's text on Sephardic women and the memory of both them and her role as a cultural spokesman were at risk numerous times of a disappearing forever from view. Let us recall that Bohoreta's text was created in the interwar period in the Kingdom of Yugoslavia during a revival of Sephardic culture, among a community that had defined Sarajevo for centuries as the symbolic "Little Jerusalem" (Yerushalayim chico) due to its multiethnic and multicultural character. Bohoreta's manuscript helped shape a conglomerate of individual memories through a process of communication that transmitted an intergenerational message, containing a strong charge of cultural energy. World War II and the Holocaust not only fundamentally changed the status of the Jewish minority in Bosnia and Herzegovina, ${ }^{41}$ but also radically transformed the political, social, and religious situation in the so-called second, socialist Yugoslavia, where the supranational, Josip Broz Tito's idea of "brotherhood and unity" was promoted, while the role of individual ethnicities within the federal state (including on religious issues) was limited. In 1992, as the greatly reduced Sephardic community was observing the 500th anniversary of the expulsion of their ancestors from the Iberian Peninsula, federal Yugoslavia was breaking up into smaller nation states, and besieged Sarajevo had become the scene of fratricidal battles laced with bitter nationalism and ethnic division. In 1995, ten years before the publication of the translation of Papo's book about Sephardic women in Bosnia, Bosnia and Herzegovina became a new state "under construction." It has experienced a difficult transition, which continues to this day, in which the memory of the Sephardic community has not been a priority. Thus,

${ }^{41}$ Karl-Markus Gau $\beta$ wrote that of the 14,000 Jews in Sarajevo before the war, only 900 remained there after it ended. Cf. Karl-Markus Gau $\beta$, "Ostatni: Sefardyjczycy z Sarajewa," in id., Umierajacy Europejczycy: Podróże do sefardyjskich Żydów z Sarajewa, Niemców $z$ Gottsche, Arboreszów, Łużyczan i Aromunów, trans. Alicja Rosenau (Wołowiec, 2006), 5-47. About the language situation of Sephardim also wrote Agnieszka August-Zarębska, "Ladino czy judezmo? O językach Żydów sefardyjskich,” Prace Filologiczne 56 (2009), 85102; and Agnieszka August-Zarębska, Zuzanna Bułat Silva, "Recalling the Past: Linguistic and Cultural Images of the Kurtijo Sephardic Courtyard," Anthropological Journal of European Cultures 25 (2016), 1:96-117. See also Izabela Olszewska, Aleksandra Twardowska, "Yiddish and Judeo-Spanish as Determinants of Identity: As Illustrated in the Jewish Press of the First Half of the Twentieth Century," Colloquia Humanistica 5 (2016), 79-103; and Tracy K. Harris, Death of a Language: The History of Judeo-Spanish (Newark, 1994). 
a remarkable and surprising phenomenon has been the recovery in the late twentieth and early twenty-first centuries in quite unfavorable circumstances (a state of tension and political ethnicization) of a text around which the cultural memory of nearly forgotten Sephardic women began to coalesce. After more than seventy years of hibernation, on the fringes of the wider mainstream culture, in the hermetically sealed capsule of the Ladino language, Laura Papo's message was disseminated in a transcultural manner. The translation should be appreciated all the more, because-let us not forget-after 1941 (after the outbreak of World War II in Yugoslavia) the Ladino language in Bosnia (for the preservation of which Bohoreta fought before the war) lost its effective power, and after 1991 generally attained the status of a language that was not only endangered in Bosnia, but already disappearing. ${ }^{42}$ The translation into Bosnian, therefore, helped revitalize the memory of Sephardic women, effusing it with new cultural energy. After 2005, Papo's work was recognized not merely as a Sephardic achievement, but was also included into the wider field of the cultural heritage of Bosnia and Herzegovina as an integral value. Paradoxically, however, the "freeing" of The Sephardic Woman in Bosnia and its full activation in the cultural memory had only been made possible by the act of translation from Ladino into a language that for centuries had historically existed alongside Sephardic culture, but remained outside of it: Bosnian. ${ }^{43}$ Yet, this language was an instrument with a somewhat wider scope of influence, though, admittedly, its own range was generally limited. Although it functioned locally/regionally and remained mainly within the culture of the former Yugoslavia, it benefited from the legacy of the wider Serbo-Croatian language system. The transcultural flavor of this second strategy was strengthened by the very interesting fact that the author of the translation which unleashed the energy of the memory of the Sephardic Jews in what was recently "Little Jerusalem" is a Bosnian with Muslim roots. It was he-alongside Krinka VidakovićPetrov and Dina Katan Ben-Zion-who became their spokesperson in the cultural memory and an active link in reconstructing the community's past in Bosnia. This speaks of the very interesting, positive patterns in Muslim-Jewish relations in this region, and of the historical Bosnian

${ }^{42}$ Ibid.

${ }^{43}$ Until 1991, the language was named Serbo-Croatian, but after the collapse of Yugoslavia the language system was divided into Serbian, Croatian, Bosnian, and Montenegrian. In the interwar Kingdom of Yugoslavia, the language was also named Serbo-Croatian. 
experiment to build an undivided community of Islam and Judaism in Bosnia and Herzegovina. ${ }^{44}$ This is a paradox and constructive irony of modernity - the survival in memory and culture of the world of Sephardic Jewish women is largely due to a Muslim.

\section{Cultural Transfer and the Transmission of Memory}

The third, rather contemporary strategy for the survival of the memory of Sephardic Jewish women (including Papo herself and her family, particularly her four sisters) is cultural transfer. We owe this strategy mainly to the literary activity of the contemporary Serbian writer Gordana Kuić, who was born in Serbia during World War II in 1942 (and thus in the year of Papo's death, a fact which symbolically underscores the continuity of activities related to Sephardic women's culture), after her parents fled from Sarajevo. She is an author with Serbian (after her father) and Sephardic (after her mother) ${ }^{45}$ roots. Laura Papo Bohoreta was the writer's aunt, the sister of her mother Blanka Levi, and appears among a palette of other heroines-Sephardic Jewish women - as a literary character in her debut novel Miris kiše na Balkanu [The Scent of Rain in the Balkans, 1986], the first volume of a tetralogy and of a series of other books she wrote on the history of Sephardic Jews. ${ }^{46}$ The novel begins the saga of a Sephardic family from Sarajevo told from within the matrilineal order, and thus from a feminine perspective. The writer, who fictionalized the microhistories of Sarajevo's Sephardic women, nevertheless drew abundantly from the history of the previous generation of women in her own family. The names of the sisters are authentic (Laura, Blanka, Nina, Klara, and Riki/Rifka); in the novel only the family's surname is changed-instead of the Levis, the Salom family appears in the book. The basis of the Serbian author's saga was the story of her mother and her sisters (with

${ }^{44}$ It is worth noting that the famous Sarajevo Haggadah (medieval codex of Sephardim) was also saved by Bosnian Muslims during World War II. Cf. Gau $\beta$, "Ostatni," 44-45.

${ }^{45}$ Privately Blanka Levi (i.e. Branka Kuić, mother of Gordana Kuić, who during World War II changed her name "Blanka" to the Serbian "Branka" and later officially used this name) was the younger sister of Laura/Luna (Levi) Papo; she survived the war in Serbia and after the war lived in Belgrade. She held some of her sister's manuscripts, which she sold in 1961 to the City Archives in Sarajevo.

${ }^{46}$ The remaining volumes are Cvat lipe na Balkanu (1992), Smiraj dana nad Balkanom (1995), and Duhovi nad Balkanom (1997). In addition, she also published other novels about the history of Sephardic Jews, and in particular, the history of Jewish women: Legenda o Luni Levi (1999), Bajka o Benjaminu Baruhu (2002), Roman u slikama (2015). 
her two brothers, Isak and Elias, marked only in the background). This first volume of the tetralogy covers the history of the family from the attack in Sarajevo on 28 June 1914 until 1945, the end of World War II in Yugoslavia. Later volumes cover the history of postwar Yugoslavia up to the 1990s and are more specifically a family micro-history told against the background of socialist Yugoslavia's macro-history until its collapse. Laura Papo, no longer one of many, but now a main character, is also the protagonist in Kuićs epistolary-journalistic novel Balada o Bohoreti [The Ballad of Bohoreta, 2006]. Both books enjoyed great popularity in Serbia and beyond, and each went through a dozen or so editions, attaining the status of pop cultural (mega-)hits and, along with Kuić's other novels on the history of the Sephardic Jews in the Balkans, have strengthened the cultural memory of Sephardic Jews in Serbia, especially the memory of Sephardic women. In this way, Kuić at the turn of the twenty-first century, just as Laura Papo had done at the turn of the 1920s and 1930s, fulfills the obligation to shape the communicative memory of her family, while maintaining a social commitment to the cultural memory of the Sephardic women's community in Bosnia, from which she also in part (through her mother) traces her origins. It is through this memory, through the Ladino language and the exclusively Bosnian Jewish cultural space, that the Bosnian language used in the translation of Papo's book penetrated Kuić in a transcultural way as an important subject for an even greater regional culture, that is, Serbian. It should be remembered that the first volume of the tetralogy, The Scent of Rain in the Balkans, appeared in print in 1986, and so was within the formula of the "broad" homeland, that is, before the break-up of federal Yugoslavia, and hence had a greater impact. This time, the strategy of cultural transfer from Bosnia to Serbia (though the author is a Serbian writer) shifted from an authentic family document to the fictionalization of the history of Sephardic women, which significantly broadened the scope of the audience, in part due to the fictional nature of the texts. The popular form of the novel/story of the Sephardic women, using the threads of a family saga and (auto-)biographical motifs, becomes easier and more attractive in its reception, drawing in the average reader with its "authenticity." Kuić thus introduces the stories of Balkan Jewish women to the collective imagination of a mass audience in contemporary post-Yugoslav pop culture. It should also be added that in recent decades the spectrum of artistic forms popularizing the stories described by Kuic has also widened. A few years ago, ballet and theatrical productions were 
made based on The Scent of Rain in the Balkans,${ }^{47}$ a TV series based on this novel was aired ${ }^{48}$ and numerous translations of The Scent of Rain in the Balkans were published in many large (English, German, French, Spanish) and smaller (Hebrew, Italian, Polish, Slovenian, Macedonian) languages. ${ }^{49}$ It is clearly visible that through its transmission to other languages of the arts (ballet, theater, film) and foreign languages (mentioned above), we achieve an even wider field for strengthening the strategies for the survival of the memory of Sephardic women in culture, and obtain a much more complete picture regarding the range of cultural transfer and the various vectors within which it flows.

One should not forget that cultural transfer is a dynamic process, born in the interaction between cultures, and derives from the feedback, mutual fascination, and/or inspirations these exchanges create. ${ }^{50}$ This involves a transcultural interpenetration of codes and tracking of mutual dependencies, intertextual relations/connections, and the continuation or transformation of cultural material. It often depends on the "reception situation/boom" ${ }^{51}$ or cultural mobility, and may involve a radical reversal in the relationship between the source culture (in this case, Sephardic culture) and the host culture (Serbian culture, and through translation, to other, larger ones). It is also important that in interacting with one another, cultural phenomena, which were not previously placed at the center of a broader historical cultural narrative, regain a place in the

${ }^{47}$ For example, performed on the stage of the National Theater in Sarajevo in 1991 or another-in Belgrade in the Madlenianum Opera and Theatre, a dramatization by Nebojša Romčević, directed by Ana Radivojević-Zdravković-premiered on 12 April 2009.

${ }^{48}$ First the series Miris kiše na Balkanu was produced for the RTS (Radio-Television of Serbia) station in fourteen episodes and aired from December 2010 to March 2011 (dir. Ljubiša Samardžić), then the second chapter of a family history based on the Kuić novel Cvat lipe na Balkanu was filmed in thirteen episodes in 2011 and 2012 (dir. Ivan Stefanović). Both enjoyed and continue to enjoy great popularity with viewers, including versions broadcast via YouTube with subtitles in English, which has significantly increased the reach of both series.

${ }^{49}$ Into French (Lausanne, 2000), English (Belgrade, 2004; the US, 2012), Macedonian (2011), Slovenian (2012), Polish (trans. Magdalena Wąs, Borderlands/Pogranicze Foundation in Sejny, 2012), Hebrew (Reah ha-geshem ba-Balkan, trans. Dina Katan Ben-Zion, Jerusalem 2012), and most recently German (Vienna, 2015), Italian (Turin, 2015), and Spanish (Madrid, 2015). More information on translations can be found on Gordana Kuić's official website: http://www.gordanakuic.com/pages/prevodi.htm [retrieved: 3 Nov. 2017].

${ }^{50}$ Paweł Zajas recently wrote about this phenomenon, although in the context of other cultures, approaching it also from a theoretical perspective. Cf. Paweł Zajas, Niemilknace muzy: Wydawcy, pisarze, thumacze i pośrednicy kulturowi na frontach Wielkiej Wojny (19141918) (Poznań, 2016).

51 Ibid., 25. 
collective memory. ${ }^{52}$ We are dealing here with just such a consolidation of the memory of Sephardic women through various cultural transfers in the work of Gordana Kuić and translations of her work into foreign languages, as well as into the language of film and other arts. The great commercial success of the author's texts shows that the aforementioned strategy of transmitting the memory of the Sephardic women through the use of literature/popular culture seems to have reached a broad, mass audience, and thus - at least for now-is not threatened with oblivion or a loss of memory. One is left, however, with the fear that through acts of massification and a broader impact, it is exposed in some sense to a process of trivialization or commercialization. However, forgetting is definitely not a threat.

\section{Digitization of Manuscripts and Archival Texts}

Today we can also observe yet another, more academic process of restoring memory, mainly through the figure and work of Laura Papo Bohoreta. I am thinking here of another strategy for survival in memory, one resulting from a combination of older methods and that make use of advancements stemming from achievements in the modern technosphere. This includes the digital archiving of texts and making use of the innovative possibilities offered by the dynamically developing digital humanities. The digitizing of texts allows them to be more quickly replicated and placed in the public sphere, which ideally supports the strategy of rescuing these texts from oblivion, disseminating them, and improving access to them. This strategy is also to be used to ensure the protection and preservation of other texts (dramas, stories, readings, poems, articles, lectures) written by Laura Papo Bohoreta about Sephardic women, and not just her study The Sephardic Woman in Bosnia. This work is being overseen by a former student and now continuator of the work of Muhamed Nezirović, University of Sarajevo professor Edina Spahić, as well as by professor Cecilia Prenz Kopušar of the University of Trieste and Sejdalija Gušić of the Historical Archive in Sarajevo (Historijski arhiv Sarajevo), with the financial sponsorship and commitment of the Embassy of the Kingdom of Spain in Bosnia and Herzegovina. This work was carried out over three years (2015-2017) in a project titled "Digitization and Publication of the 
Private Collections of Laura Papo Bohoreta," the effects of which are already apparent. A pilot project and inspiration for the creation of the project for the preservation of manuscripts of Laura Papo's works was the publication of a digital version of her best-known and most often staged and popular drama Esterka: Ritrato social de nueastros dias en tre actos [Esterka: Scenes from Social Life in Three Acts] from 1930. In 2015, the first of three notebooks was published containing the manuscripts of Papo's dramas: Ožos mios [My Eyes], Avia de ser [It Used to Be So], La pasensia vale тис̌о [Patience Worth Its Weight in Gold], and Tiempos pasados [Past/Old Times]. The second notebook, which appeared in the autumn of 2016, contained dramas: Shuegra ni de baro buena [A Mother-in-Law Even Made of Mud Is No Good], Hermandat-Madrasta - el nombre le abasta [Brotherhood of the Stepmother - a Name That Speaks for Itself], and the aforementioned Esterka. ${ }^{53}$ The third notebook appeared in June 2017 and contained essays, poems, texts about Sephardic customs, one-act plays, and Sephardic romances (romanceros) collected and preserved by Bohoreta. In this way, the digitized and published manuscripts of Papo were first secured in a larger number of copies, which protected them against loss or destruction. Second, their scope of access was expanded. They entered into a new, wider range of circulation, and were now available not only to a narrow group of privileged researchers, but had a path to bring them to a wider, interested audience. It must be remembered, however, that the publication of the three volumes of manuscripts from the Municipal Historical Archive is just the first stage of this project. Although these manuscripts have been secured and digitized, they still exist only in the Ladino language, and can only be read by people who know this language, which, as mentioned earlier, is a very narrow group, giving Ladino the status of an endangered language. In fact, the work of Papo would have attained a wider field of influence in the culture of the region if-like the study The Sephardic Woman in Bosnia-it had been translated into Bosnian. However, this stage still lies ahead. Nevertheless, the digitization and publication of manuscripts is a strategy for the protection of endangered elements of the national heritage of Bosnia and Herzegovina, the category under which the legacy of Laura Papo

${ }_{53}$ We should also remember that Eliezar Papo has recently edited a critical edition of Bohoreta's drama Avia de ser in Judeo-Spanish. See Eliezar Papo, "Avia de ser, escena de la vida de un tiempo, kon romansas, de Laura Papo 'Bohoreta': Edision sientifika, anotada i komentada," in Paloma Díaz-Mas, Elisa Martín Ortega (eds.), Mujeres sefardíes lectoras y escritoras: siglos XIX-XXI (Madrid-Fankfurt, 2016), 339-364. 
Bohoreta has been officially placed. Thus, the memory of Sephardic women has passed through two stages in the overall trajectory: lost-written and lost-regained. The third phase-revision-is still ahead of us, although the first signs of progress are visible. In this academic context, we should welcome with joy the first full monograph devoted to Laura Papo, written by the Croatian researcher Jagoda Večerina Tomaić, entitled Bohoreta najstarija kći [Bohoreta - The Eldest Daughter] from 2016. This author in 2017 also published a book in Spanish entitled Laura Papo Bohoreta, en el confin de mundos, culturas y lenguas: El estudio de la vida y obra de Laura Papo Bohoreta, primer escritora sefardí [Laura Papo Bohoreta, on the Crossroads of Worlds, Cultures and Languages: A Study on Life and Work of Laura Papo Bohoreta, the First Female Sephardic Writer], which brought knowledge about Papo to Spain. ${ }^{54}$ This country abounds in fateful significance in the cultural memory of Bosnia's Sephardic Jews, and has become the setting of a mythic prehistory and a metaphor of the lost homeland, both of which also functioned during the times of Papo as a mnemotopos, ${ }^{55}$ a symbolically saturated place, evoking the memory of the Sephardic paradise from before their expulsion in 1492. The return of Laura Papo Bohoreta to the Spanish language through the Croatian Sephardic studies scholar Večerina Tomaić can therefore be regarded as somewhat symbolic.

\section{Conclusion}

Over the last hundred years, a transnational (Sephardic-Bosnian-SerbianCroatian-Spanish) space of communication has developed, contributing to the preservation of memory of Sephardic women in Bosnia. This memory work was initiated by Laura Papo Bohoreta, who collected and wrote down the lore of her female compatriots. At the same time, the memory of Papo herself as one of the most spectacular figures among Sephardic women from Bosnia is also being preserved and revived. The four strategies I have distinguished for preserving memory, not only that of Laura Papo, but, first of all, of the Sarajevo/Bosnian Sephardic women's community

${ }^{54}$ See also Nela Kovačević, "El mundo sefardí en la obra de Laura Papo y el papel de la mujer en él" (Ph.D. dissertation, Universidad de Granada, 2014). I am grateful to Željko Jovanović for paying my attention to this text.

55 Jan Assmann has written on the phenomenon of mnemotopos. Cf. Assmann, "Kultura pamięci," 92-93. 
described in her copybook in 1932, have followed a spatio-temporal trajectory of mutual communication, based on the cultural mobility of the materials dedicated to Sephardic women. Each of these strategies-Laura Papo writing down the history of Sephardic women in Ladino in order to restore their dignity and highlight their relevance to the history of their own culture; later, the translation and publication of Papo's writings about Sephardic women (Muhamed Nezirović); then its cultural transfer and popularization in novelistic form (Gordana Kuić); and finally, the ongoing archiving and digitization of Laura Papo's remaining works (an international project) and serious academic interest in these texts (Jagoda Večerina Tomaić as well as Krinka Vidaković-Petrov, Eliezer Papo, and Željko Jovanović)—seems to have been well selected by the actors behind the transfer, who have played a role in creating the cultural memory of Sephardic women in Bosnia. Each of these strategies seems to have been optimal for the particular moment in time that it emerged and facilitated a maximum of success for the given conditions and specific historical moment. Through their interactions with one another, cultural phenomena that were previously not central to the narrative assumed a place in the collective memory. And all four strategies seem to have been necessary, each in its own time, while their combined power arises from their mutual complementarity. Moreover, only now, in the paradoxical situation of the very small remaining population of Sephardic Jews in the countries of the former Yugoslavia, serious studies on Sephardim have begun and the process of creating their cultural memory has originated. A testimony to this-in addition to the events and artefacts described above-is the "Bohoreta" women's club, established in the 1990s in Sarajevo by the "La Benevolencija" Jewish cultural, educational, and humanitarian association, and named in honor of Laura Papo. The charity association "La Benevolencija" was founded in 1892 to serve the Jewish population, and Papo was a committed activist for the cause during the interwar period; having ceased its activities in 1941 it was reactivated in 1992, a century after its founding, and continues to operate to this day. ${ }^{56}$ Papo devoted her book on Sephardic women to this organization, writing: A la "Benevolencija” valeros amiga del progreso ("To 'La Benevolencija,' a brave friend

${ }^{56}$ More on the history of the association can be found on its official website http:// www.benevolencija.eu.org/content/view/33/35 [retrieved: 6 Nov. 2017] and in the text by Anna Bianca Roach, "La Benevolencija," http://balkandiskurs.com/en/2017/04/03/englishla-benevolencija [retrieved: 6 Nov. 2017]. 
of progress"). The women's club associated with the "Bohoreta" club has a double meaning. On the one hand, it commemorates the name of Laura Papo and is a symbolic continuation of her work in spreading knowledge about Sephardic women, and, above all, plays an important social and humanitarian role (helping the elderly, the poor, taking care of children, organizing celebrations of Jewish holidays). On the other hand, it refers not to the name of the writer, but to her nickname "Bohoreta," which the firstborn daughters, the eldest sisters, in Sephardic families had bestowed upon them. This idea of a symbolic cultural sisterhood among contemporary Sephardic women in Bosnia and the region (post-Yugoslav countries) is also a form of commemoration of its patron and a specific space of memory. However, it primarily activates the metaphor of female subjectivity in active solidarity and emphasizes the continuation of the path taken by the "oldest sister." It also emphasizes a unity built around a Sephardic/Bosnian identity, with an emphasis on the women's community. One thing is certain. Thanks to the numerous survival strategies launched in the past and today, we are slowly beginning to recover the memory of Sephardic women and to update and revitalize it. 